\title{
Postcolonial Hermeneutics: Concepts and Contribution to Understanding Socio-Religious Problems in Southeast Asia
}

\author{
Novita Dewi ${ }^{1}$
}

\begin{abstract}
Scrutiny of unequal power-relations between the "East" and the "West" in politics, culture, economy, and various aspects of life is the concern of postcolonial studies. Foucault's concept of power is central in postcolonial theory with which Edward Said is celebrated for his dismantling of Orientalist views. Postcolonial literature, likewise, has contributed to the growth and development of postcolonial criticism. The first objective of this article is to give a brief overview of different terms attached to the word "postcolonial", i.e. postcolonial literary criticism, postcolonial literature and postcolonial theory, since these terms enrich one another theoretically. The second objective is to discuss postcolonial hermeneutics as a reading tool to examine various mundane practices in Southeast Asian postcolonial society. The purpose is to achieve a balanced, reciprocal exchange of perspectives while providing legitimacy for alternative interpretations to the hegemony shown in "Western" discourse. Citing traditional ways of conflict resolution and eco-friendly land management as examples, this article concludes that postcolonial reading may shed light on how socio-religious conflicts, hybrid experiences of faiths, and other social practices operate and get their respective meanings in postcolonial countries across Southeast Asia.
\end{abstract}

Keywords: Postcolonial Identity, Hybrid Experiences, Traditional Wisdom

\footnotetext{
${ }^{1}$ Lecturer at the Graduate Program in English Language Studies, Sanata Dharma University, Yogyakarta, Indonesia.Corresponding e-mail: novitadewi@usd.ac.id; novitadewi9@gmail.com
} 


\section{Introduction}

Intended primarily as an introductory text for students new to postcolonial literary criticism, this article begins by recalling two short stories by the Nigerian novelist Chinua Achebe (1931-2013) entitled "Marriage is a Private Affair" and "Dead Men's Path". The first story tells of Nnaemeka from the city of Lagos who is engaged to the girl of his dream and dares not to tell this good news (or bad) to his father Okeke. At the persistent encouragement of Nene his fiancée, the young man returns to the village and a conflict with the father soon ensues for the older man has chosen a "Christian-educated" girl who "read[s] the Bible fluently" to be his son's wife. Nnaemeka however is determined to come back to town and marry Nene. Six months later, when receiving his son's wedding photograph, Okeke cuts off the bride's picture and sends it back via snail mail because for him the daughter-in-law has never existed. Years and seasons change, father-and-son relationship become increasingly tenuous, although Okeke hears that his son makes no mistake in marrying Nene, because she is a smart and kind wife. Eight years later, Nene ventures to write a letter to her fatherin-law to inform the arrival of her husband and two sons who are all eager to see their grandfather, while she herself would remain in Lagos. At that point, sad and sorry is Okeke. At the same time, the old man is afraid if no time is left for him to make peace with his son, daughter-in-law and yet-to-see grandchildren.

The main character of the second story is Michael Obi, a young headmaster who is given a new assignment to lead a school in the village. Together with Nancy, his fashionable wife, Obi eagerly wants to rebuild a modern school, both in terms of depth of vision and mission and physical appearance by, among other things, setting up a Western-style garden and school ground. One day, Obi is shocked to see a procession of people passing through the schoolyard bringing offerings to a nearby cemetery. Obi immediately orders that the shortcut be closed without a prior discussion with the locals. Protests from residents and warnings from village elders are largely ignored. For Obi, the ritual of worships to the ancestors is contradictory to the spirit of modernization being underway in the village. Until one day there is a catastrophic incident when a young woman died in childbirth. Soon the villagers rampage the school by knocking down the fence and destroying the beautiful garden. When the school inspector comes, Obi receives a letter of dismissal for being incompetent to manage the school entrusted to him. 
Thus being said, criticism of power-relation is read in the two stories above when modern culture is confronted with traditional non-Christian values; the rational v. the irrational; "Western" v. "non-Western", and so forth. Written by a Nigerian with European and Christian education background (Achebe's father is a priest), these short stories depict resistance to colonial and autocratic discourse toward the African nation as a once-colonized nation. While acknowledging the positive influence of Christian missionary, Achebe was critical of its often condescending attitude toward African culture (Purcell, 2013). Being a Christian himself, Achebe perceived hypocrisy in some fellow new-born African Christians. To compare, Tayeb Salih's short stories portray the pretentiousness of the predominantly Muslim society in Sudan, just as Pramoedya Ananta Toer' writings often do with some certain characters (See Dewi, 2017).

So what does it all to do with the Southeast Asian society nowadays? Being members of each own postcolonial society, Achebe, Salih and Pramoedya are among few writers capable of self-criticisms and reflections. Despite the end of colonial rules, the Southeast Asian people, like other colonized African nations, need to discuss colonialism, especially the psychological effects and socio-cultural transformations it produces. The supremacy of global power in colonial times is still felt today; and "nonWestern" nations should be given all means and opportunities to voice themselves. This is where postcolonial hermeneutics play an important role in religiosity and other societal aspects of life that this article seeks to address.

This article firstly aims to delineate three related terms attached to "postcolonial", i.e. Postcolonial Literary Criticism, Postcolonial Literature, and Postcolonial Theory. The three terms give historical and theoretical footings to one another. As such, a brief look at Edward Said's notion of power-relations is important as it essentially underpins Postcolonial Studies. The second objective is to examine Postcolonial Hermeneutics as ways of reading in interdisciplinary fields including Theology, Social and Religious Studies, particularly its relevance to Southeast Asian contexts today. 


\section{Theoretical Concepts}

The publication Orientalism in 1978 by Edward Said uncovers the Eurocentric principle, i.e. false notion of a definite "Oriental" ("non-Western") life in "Western" imagination imposed on all "Eastern" people. He uses the concepts of discourse of power/knowledge from Michel Foucault to develop the conceptual basis of Orientalism by saying thus:

Orientalism can be discussed and analyzed as the corporate institution for dealing with the Orient - dealing with it by making statements about it, authorizing views of it, describing it, by teaching it, settling it, ruling over its: In short, Orientalism is a "Western" style for dominating, restructuring, and having authority over the Orient. (Said, 1991, p. 3)

Foucault's contribution to Said's work is clear: "Orientalism" is a "Western" discourse. Here discourse is interpreted as a cumulative product in language and culture about how the "West" speaks, portrays, thinks and imagines the "(Middle) East" and the other with high authority (power) so as to be called "knowledge". Following Nietzsche's idea of "will to power", Foucault believes that power does not come from a single person, class, nation or country, but rather a general and spreading phenomenon that circulates through society (Said, 1991, p. 337). Discourse as power is a certain and convincing way in which power expresses itself in society through "knowledge" of human beings and their particular observable facts through, for example, academic texts, mechanism of control, literature and culture. Knowledge here means the way of naming and placing the discourse, that is, information gathered about people and the world that substantively enters into the discourse to which it is created. The identities and categories of discourses of this kind are very subjective (biased), and if one's experience is not in line with that of the authorities, she/he is subject to exposure, punishment and coercion. This is often discussed by Foucault in relation to his "panopticon" model derived from the social theory of Jeremy Bentham (see, for example, Mathiesen, 1997; Wood, 2007).

It becomes more obvious by now that a special discourse on "Orient" or "Eastern" called "Orientalism" has grown in the tradition of "Western" thoughts. It is an authoritative and substantial voice from the "West" claiming and defining exactly what the "East" really is. Knowledge of the "East", the vocabulary, the imagination as well as its institutions are mutually supportive with the physical colonization by the European countries since the $16^{\text {th }}$ century. 
Colonizing tendency continually occur to date partly because the "Western" world fails to understand heterogeneity. The "West" refuses to look at the diversity of cultures in the (former) colonies that have been explored for centuries. Examples of past failures are countless. Columbus thought Indians in America were Indians in the New World who had to be conquered. Such is a myth living to the present although debunked progressively by scholars from different fields from history to language and literature studies (Wardaya, 2017; Restall, 2004; Zitzer-Comfort, 2008). This failure continues as European powers at the Berlin Conference promote the establishment of a new country in Africa regardless of the diversity of ethnic groups and imaginary territorial borders that have been created since time immemorial. The European countries claim themselves as being responsible for the civilizing efforts by introducing liberalization, democracy and development to African countries (Andreasson, 2005). A less clear and (mis)informed "Western" understanding of the Middle East and Asia continues to produce stereotypes, generalizations, and an increasingly unified idea of the Other. "Western" view of Islam as a solid league of "terrorist" continues to thrive to date, especially with the brutality of acts of terror and cruelty in the name of Islam.

It is clear that the "West" treat the Other as if they lived in the past, hence denying their historical presence. Being removed from history, the "East" is made non-human, i.e. inventory items only. The "West" sees the Other as objects -pure and exotic- that can be used at will. "Western" discourse regards "Eastern" ("non-Western") people as if they had never been touched before the European civilization came to "tame" them, as claimed by Said in his essay "Representing the Colonized: Anthropology's Interlocutors" (1989). Without history, these marginalized people are again vulnerable to "Western" powers who claim history and agency for themselves. The power of colonial discourse to speak (good) about themselves has stripped the colonized peoples of their rights to speak up. Without a voice, the colonized Other is usually the object of discourse and is almost never a subject. It is in Covering Islam that this Christian Palestinian unveils the "East-West" imbalances. Reviews and criticisms of British novels are detailed by Said in Culture and Imperialism. The works of Said play an important role in dismantling the power-relations read through the works of European literature on "Western" discourse of the "East". 


\section{Method of Study}

The nature of this study is that of explicatory research, focusing as it does on careful, close, and intensive examination of major texts on a single complex event in order to understand one or more aspects of it (George, 2008, p. 6). The texts in question are existing studies on Postcolonialism, while the event (s) and the aspect(s) thereof are power-relations that occur in everyday practices in Southeast Asian countries. Using library research for data gathering, the study examines reference books and journal articles by treating them as both primary and secondary data not as mutually exclusive but can sometimes be overlapping (George, 2008, p. 56). In so doing, articles/ books on postcolonial literature, postcolonial theory, and postcolonial criticism culled from both primary and secondary sources are classified as Data Type One. Data Type Two, obtained by the same method, comprises of books and articles on Southeast Asian studies. To maintain the recentness of the study, only studies of 10 years old or newer are included, excepting for some classic works like Said's Orientalism that becomes the quintessential scholarly work in postcolonial studies. Content analysis is applied in reading and interpreting the data to change "imagination" into "insight" as customarily done in library research process (George, 2008, p. 66). What begins as a close reading of power-relations represented in literary works (Step 1) later becomes a "closer" reading of daily oscillation of different powers in postcolonial society of Southeast Asia (Step 2).

This study's trajectory is thus enabling literature to encounter with philosophy, history, theology, and geography, hence application of interdisciplinary approaches to literary texts (Johnson, 2010, pp. 6-141). Simultaneously, this study agrees with Sunardi (2002) in his claims that literature should become the basis of humanities studies given its contribution to social theory and society (See also Dewi, 2006). What follows is a glimpse of different but related concepts of Postcolonial Literary Criticism, Postcolonial Literature and Postcolonial Theory along with each proponent.

\section{Discussion}

Postcolonial Literary Criticism, Postcolonial Literature and Postcolonial Theory in Brief

Postcolonial Literary Criticism can be found, among others, in the writings of Chinua Achebe and Ngugi wa Thiong'o especially in the use of language. According to 
Achebe, English is the language to use to discuss the suffering of colonized African people to the world. In contrast, Thiong'o argues that decolonization is possible if African writers abandon colonial language. The book of criticism of Postcolonial Literature by Ashcroft, Tiffin and Griffiths The Empire Writes Back first appeared in 1982 is a practical guide to reading literature using postcolonial approach. This book helps to see whether a work is a "colonial discourse" in which distortion of reality and the experience of the oppressed is normalized; or "colonized discourse" that performs articulation and reclamation of identity (Ashcroft et al., 1991). Postcolonial perspectives help scrutinized the power- relations between the oppressor and the oppressed. This imbalanced relationship also applies to the category/ identity of subjects who experience a similar process of colonialism including the colonization done by the fellow people of the country. Simon During (1987) uses the term "postcolonizing" for oppressive subjects in the post-colonial era, and "poscolonized" for the oppressed objects. Such unjust power may occur between majority and minority, indigenous and non-indigenous, Muslim and non-Muslim, Christian and anti-Christian, and so on. In this case, the critique of postcolonial literature can contribute to other disciplines in the humanities.

Next, known as writers of Postcolonial Literature are Jean Rhys, Salman Rushdie, Margaret Atwood, Michael Ondaatje, and Arundhati Roy. Their writing is a counterdiscourse or re-work of the narratives often found in canonized European Literature. To mention but one example, Jean Rhys deconstructs Charlotte Bronte's Jane Eyre (1847) by retelling the story of the marginalized figure in the classic English novel. In Wide Sargasso Sea (1966), Rhys narrates the other side of the menacing story of the mad woman, Lord Rochester's first wife in Jane Eyre. The Creole women's suffering is told in the new novel so that readers can see the cruelty of the white male characters whom in the old novel looks "fine".

As for Postcolonial critics, Edward Said is often called one of the "(Un) holy Trinity", along with Hommi Bhabha, and Gayatri C. Spivak as they are considered prime movers the Postcolonial Theory. Making use of British and French novels as illustrations, Said supports his views on colonial/imperialistic power-relations and "Western" claims of the Otherness of inferior "Eastern" cultures. In addition to the three authors, Franz Fanon, Aime Cesaire, Albert Memmi, Achilles Mbembe, Henry Louis Gate, Jan Mohammed, and Robert Young are important figures with 
indispensable views in Postcolonial Studies. In varying degrees, these thinkers use novels, dramas, or other literary works to provide explanations about the unequal relationships between the rulers and the ruled, the colonizers and the colonized, the oppressors and the oppressed, and so forth. Because some of these names are also literature scholars, they, too, are known for their postcolonial praxis. For example, Cesaire wrote $A$ Tempest (English translation [1986]) from the original French version (1969) which is a writing back for William Shakespeare's The Tempest (1610).

To discuss Cesaire's rewriting at length for clarity sake, this Francophone Caribbean writer relocates Shakespeare's fictional setting from an island in the Mediterranean Sea in the 16th century to Haiti. In the old work, Caliban, Prospero's servant is the witch Sycorax's son cast as half-animal and half-human being. He is later converted to Christianity, thanks to the guidance of the White Master. In Cesaire's play, conversely, Caliban rebels and perceives the white men as big liars. Prospero's the Duke from Milan in the rewritten work becomes a mere companion for the duo-blackand-mulato Caliban and Ariel. Prospero who returns to Milan in Shakespeare's drama is retold in the new play: He resides in Haiti. Since the target audience is different, different sub-texts appear. The play of Shakespeare, watched mostly by the White audience, conveys a message that despite the conquest of the natives, the White colonizers nonetheless are compassionate. On the contrary, the spectators of Cesaire's play are colored people who are expected to capture this sub-text: Negotiations and cooperation are required to end colonialism. It is clear here that literary works can be rewritten to reveal the other side that has so far been invisible.

Postcolonial Criticisms and Theory (or Postcolonial Hermeneutics) can therefore be used as reading tools to rediscover the lost experiences and perspectives of the colonized subjects. The remaining part of this article is to examine the use of postcolonial hermeneutics in discussing problems in studies pertaining to social and religious studies in the global age. Any religious discussion today must give space to diversity and complexity of local cultures bearing in mind that the "ghost" of colonialism still lies waiting. 


\section{Postcolonial Reading of Quotidian Experiences}

When the talk turns to either articulation or reclamation of identity, people sometimes behave to conform to the normatively defined identity as parents, students, employees, lecturers, religious congregations, citizens, and so forth. It is worth remembering that people often try persistently to ensure a particular conformity to a particular identity. Examples of identity statements abound, simplistic though they are. To be called Indonesian or Javanese, one must wear batik or speak polite Javanese; educated people should familiarize themselves with Jazz and Classics instead of Dangdut or Hip-hop, and so forth.

Muslim women, to exemplify further, are reportedly not Islam enough without wearing hijab. Indeed, in predominantly Muslim countries like Indonesia and Malaysia, hijab wearing among young Muslim women is often linked to modernity besides evidence of piety, thanks to the hype of consumerism and popular culture (Hassim, 2014; Beta, 2014; Peng, 2015; Hassim \& Khalid, 2015). Seen from postcolonial perspectives, stylishness embraced by these young urban women is not fully an adoption of the "Western" culture. For them, wearing hijab is a "local" (read: "non-Western") fashion statement, contrary to the view that it is a form of oppression (e.g. Milallos, 2007; Sloan, 2011). Here we see the interplay of power in politics, culture and economy as well as the complexity thereof.

As assessed critically by Foucault, the basic idea of power is producing knowledge not only to understand them but also to control those things as well. For him, knowledge is not related to rational inquiry or truth-seeking, as promised in the Enlightenment, but to show power. During the draconian rule of Suharto's New Order, Haryatmoko exemplifies (2016), the Indonesian citizen identity cards bear different codes to classify the native Indonesians from the Chinese descents. Speaking of power ethics, Haryatmoko maintains further that Foucault's reflection on power and resistance can be used as a strategic consideration in order that the history of intolerance since the events of 1965, May 1998, the conflicts in Tanjung Priok, Ambon and Poso are not repeated.

Recently, the Indonesian government makes it mandatory that cellular phone users register their phone numbers by validating them respectively with their identity card numbers. The aim is allegedly to protect people from cybercrimes including hate speech and hoax that contradict the state ideology, to say nothing of sex-linked crimes 
proliferating through internet. Here, the more information that is gathered about a particular person or phenomenon, the more certain people with power become about the discourse associated with it, and the more courageous these people in affirming their control over it.

\section{Postcolonial Reading of "Heaven and Earth"}

According to Stephen D. Moore, after liberation theology and liberation hermeneutics, postcolonial studies began to gain momentum by recent decades in interpreting the Bible. Bible critics in the "Western" world are intensely engaged in their task to unravel the New Testament texts "from the embrace of imperial Christianity" (2008). In Asia, Kwok Pui-lan (2005) introduces postcolonial approach to the field of feminist theology to decolonize the dominant patriarchal culture ingrained in Christianity. This is to say that the post-colonial society condition gave birth to a new discourse namely Postcolonial Theology (e.g. Brett, 2008; Keller, 2012). As an academic discipline, it examines and criticizes the dominant power structure and its ideology. The goal is to recognizes and validate alternative views of culture(s) owned by the marginalized societies. In order to create social transformation, theological reflections in postcolonial perspective deals with spiritual as well as profane issues such as nationalism, culture, gender and many more. Herein, the Word of God is approached with a hermeneutic of distrust believing that it is an inherently oppressive text. Postcolonial theology aims to seek emancipation and authenticity for all marginalized or oppressed identity. Pragmatic-based theology usually occurs when one person's experience is able to inspire consciousness, integrate existing and contextual ideas belonging to a larger community like local conflict resolutions to which discussion we now turn.

Representing the deepest desire of the Dayak Desa society in Kalimantan, Indonesia, "Kana Inai Abang Nguak" is a form of oral tradition performed in the formal ritual language by chanting. The recent study by Astuti and Taum (2017) reveals that this indigenous people's concept of Heaven and Earth differs from that of the Abrahamic religions. Heaven is not of different entity from Earth. The Dayak people believe that Earth and Heaven are created and settled by sibling ancestors who have their own order and rules to live safely and comfortably. It is natural that as siblings, they occasionally quarrel and later make peace with each other. Heaven sometimes 
makes disturbance by capturing the earth's tribal council chief. Such is a serious violation to be avenged by Earth. To deal with Heaven's attacks on the core and source of life on earth, human, animals, spirits, and magic powers gather forces to strike Heaven back to restore harmony. Here we see that this indigenous wisdom deconstructs the binary opposition of Heaven being good and Earth, bad.

Although "Kana Inai Abang Nguak" seems to appear only in imaginary level, this local wisdom provides world-views that may be different but not less significant comparing to religion proper. Indeed, Indonesia is a storehouse of local values and traditional beliefs that guide people's life from generation to generation. In the Moluccas, to give another example, people believe in a form of local customary law called "Pela Gandong", the brotherhood among beings that has drawn scholarly interests especially at the height of conflicts between ethnic Ambonese Christians and Muslims to date (e.g. Bräuchler, 2009; Hehanussa, 2009; Pattiselano, 2014; Titaley, 2018). Like in any parts of Indonesia, when clashes between neighborhoods occur, the local people have relied on the traditional agreement system of pela gandong to reduce tensions as well as resolving conflicts. It was in Western Seram that pela gandong culture brought the conflicting parties back to their senses and restored the broken relationships, turning Ambon menangiseee or Crying Ambon into Ambon maniseee or Sweet Ambon (Bräuchler, 2009; Pattiselano, 2014)

Note must be taken here, however, that the discussions about "Eastern" religions and cultures are often discriminatorily published and contained by such global authority as prominent journals in English (Bandel, 2013). Alternative discourses on religion, religiosity and religious experiences in non-Eurocentric ways is yet to disseminate. Borrowing what Walter Mignolo has called the "subalternization of knowledges" (2000, p. 11), King is right to say that border-crossing is important to engage in the conversation between the world's wisdom traditions and mainstream philosophy of religion (2009). Thus, it is not until agreeable dialogue of this kind occurs; "East-West" dichotomy is here to stay.

\section{Reading Spaces, Reading Spirituality}

Not only does postcolonial hermeneutics contribute to theology and religious studies, it also provides ground for examining the connection between religion and space. To use postcolonial literature yet again to illustrate, Michael Obi the 
headmaster in Achebe's short story contends that the ceremonial path connecting the village shrine and the cemetery contradicts rationality and Christian mission he sets out to strengthen. Acting like white colonizers by imposing his will to close the path, Obi ignores the significance of tradition to the local people. Here, Achebe's works demonstrate resistance and power struggle experienced by postcolonial subjects as shown by the wealth of postcolonial literary studies on Chinua Achebe (e.g. Tiffin, 1988; Ouzgane \& Okome, 2009; Soonsik Kim, 2004; Ekpo, 2005). Omiegbe (2004) contends that the Igbo traditional religion in Achebe's works serves the Nigerian writer artistic purpose which is helpful for the postulation of African Literature theory. Indeed, the oscillation of tradition, modernity, and sacred places is characteristic of postcolonial writings set in Africa as claimed by Nwosu (2007) pointing out, among others, the selected works of Achebe as illustrations.

The other short story "Marriage is a Private Affair", like "Dead Men's Path" is also frequently used to illustrate the intersection between (post)colonialism, religion, and space. The Canadian Jesuit Bernard Lonergan's theology of conversion, i.e. intellectual, moral, and religious becomes the approach used by Purcell (2013) to examine the formerly "decorative Christianity" of Okeke before this obstinate old man finely shows remorse and excepts his son's intertribal marriage to a non-Christian woman. Written almost a decade before the Second Vatican Council when the Catholic finally acknowledged the centrality of culture into which one can fully embrace her/his humanity, the short story, Purcell argues, illustrates the transformative conversion of Okeke. According to Purcell, it is thus simplistic to read only clash of cultures in the works of Achebe. Instead, Christianity has found a new praxis in the new place that was Africa through negotiation with the local, indigenous cultures, thanks to the Gospel's universal message of familihood and humankind.

Suffice to say that for now, postcolonial theory allows us to imagine and take into account the potency and agency of the so-called "spiritual landscape" in the conversion process. The closure of the sacred path across the modernized village school and the ensuing death of a baby in Achebe's story have helped us conceive the importance of landscape in postcolonial society. As an important agency, the concept of spiritual landscape necessitates historical process of interactions between people and environment that continually shape and reshape each other. Specifically examining Southeast Asian contexts, Allerton (2009) shows that intertwinements of 
missionaries, government/politics, and capitalism are worthy of exploration when discussing the contestations and shifts of meaning of the spiritual landscape in everyday practices in this global world. Allerton reminds us that the purification quests of the reformists (if not to say "Western") have to take into thoughtful account the agency of the landscape. Built on Allerton' views, discussed below are few examples of the significance of spiritual landscape to the local culture across Southeast Asia with regard to ecology.

Purification or civilizing mission in the name of development has often failed when the rich and prominent donor countries attempt to modernize indigenous people. While the objective of the developers is to prescribe "secular and material progress", the developees seek to maintain their "spiritually based" original culture (McCaskill, 1997, p. 29). Tribal culture hardly needs "Western" tutelage about natural resources and its utilization. The Karen people in Thailand-Cambodia border region, for example, have forest bounty at their disposal to use sufficiently using their own method of hunting and collecting nature resources. It is ironical that local knowledge vis-à-vis "Western" (read: World Religions) teaches us that the Creator's loving presence is evident in the beauty and balance of all creation. "Live with the water, care for the river", Trakarnsuphakorn rightly quotes the wisdom of Karen, "Live with the trees, care for the forest" (cited in McCaskill \& Kampe, 1997, p. 206) to show how this rural community befriends nature. On the contrary, the developers often disagree with the resources management of the Karen and other tribal farmers in Southeast Asia especially when they slash and burn their forests. Thus, these "extroverted traditionalists", to use Buergin's words (2004), get all the blame for the subsequent deforestation and watershed degradation in the highlands of northern Thailand. Politic of the blame has long been exercised to marginalize the indigenous people by robbing them off their land rights, hence the loss of their spiritual landscape. The developers are the powerful party who skillfully slide between the swidden cultivation and the swidden cultivators by pushing the rural people outside their own territory (Hirsch, 1997; Santasombat, 2004) which results in slow recovery of the place and endless suffering of the people (Fukushima et al., 2008). Similarly, the rural peasants in Ratanakiri province in northeast Cambodia have practiced for generations the traditional method of farming proved beneficial for natural balance until land rights issue threatens their way of life (Colm, 1997; Fox et al., 2009). Respects to 
sacred landscape are evident when the indigenous people practice their shifting cultivation, observing seasonal cycle, and performing many other methods of earthcare agriculture. Ratanakiri's traditional, sustainable life is gradually lost to illegal logging, military and/or multi-national company concessions; the indigenous people have no land entitlement given their lack of legal paper according to the Cambodian Law.

Another example that the marginalized and the weak are but poor players in the capitalistic game is the de-development and destruction of culture and lifestyle of the Penan in Sarawak, the Malaysian part of Borneo. As said elsewhere, under the endorsement of the Malaysian government, foreign logging companies have long conducted their ecologically destructive operation since 1980s (Dewi, 2006a). The hunter-gatherer tribe of Penan was forced to leave their rain forest and the land with which they had identified themselves. Development policy in the region is no other than extensions of government control over the peripheral. The then Malaysian Prime Minister Mahathir Mohamad had reportedly condemned foreigners like the missing Swiss environmentalist Bruno Manser for having made the Penan "anthropological specimen [...] to gawk at" (Elegant, 2001, p. 48). Initiated and mobilized by Manser, the locals attempted blockades against the existing timber companies only to be gunned-down by the military. To quote part of the Penan's scornful song about the military coercion: "We ask for pardon, you attack us/We demand to talk, you point your guns/ At our hungry wives and children/ Is this the custom of the big people?" (Dewi, 2006a, p. 14). Having no access to justice, the Penan people were so vulnerable that the ones in power, that is, "the big people" easily coerced them into living in the settlement area built in haste. Here we see that for any indigenous people, land is fundamental and sacred given its nonphysical and cultural meanings, to say nothing of the economic value and ecological sustainability. It is important to note in passing that studies in urban development, likewise, have recognized the potency and agency of spiritual landscapes (e.g. Goh, 2005; Bishop et al., 2013).

\section{Concluding Remarks}

This article has firstly shown that "Western" discourse has a dominant power to make the "East" an object of study, then to master it, and later to take control over it altogether. Although postcolonial studies with Said as a great name attached to it 
remain very important, Foucault's theory of (positive) power is useful in reading postcolonial realities in Southeast Asia today. His anti-power hermeneutics can be viewed more fittingly and contextually with the polarization of religious identity recently rampant in the country. The evidence of repeated violations of power ethics in the 2017 Jakarta Gubernatorial Election and a series of sectarian acts that follow is a case in point. Unfortunately, Indonesia as a nation-state hardly learns from the history of past violence which is the brain child of colonialism.

Next, this article has argued that the culture of the local, marginalized society is usually sidelined in the "Western" culture and politics, despite its relevance in solving internal, postcolonial problem like socio-religious conflicts. Postcolonial hermeneutics is therefore appropriate to challenge the dominant discourse (for example, World Religions) by providing a place for hybrid faith and/or religious experiences. As an alternative discourse, Postcolonial Theology recognizes and negotiates differences that enable us to hear various responses and views from all sides, in the hope of achieving a balanced, reciprocal, and representative exchange of perspectives.

Drawing examples from different regions in Southeast Asia, the article has also shown that postcolonial hermeneutics is useful to read the intersection between (traditional) religion and geography over the issue of spiritual landscape. Political, socio-economic, ethnocultural, historical, and ecological interests are often played out by the agents of developments that comprise of the developers and the developees. As such, through postcolonial lenses, power and resistance to power alike have helped spiritual landscapes to continually define and redefine themselves.

Finally, Chinua Achebe, whose two stories open this article, calls for African writers to play role as a teacher of their own culture in his famous essay "The Novelist as a Teacher". His essay persuades African writers to write differently from European writers by teaching people to understand African reality in order to free the repressed minds of the ex-colonized people. Similarly, in postcolonial Southeast Asia today, to resort to myriads of local knowledge as positive power when dealing with social problems is to liberate the colonized minds. It is thus of vital importance to use with confidence home-grown postcolonial values to challenge the dominant influence in culture, politics, economy, and all kinds of hegemonic power in pursuit of equity and humanity. 


\section{References}

Allerton, C. (November 2009). Introduction: Spiritual Landscapes of Southeast Asia. Anthropological Forum 19 (3), 235-251. Retrieved from https://doi.org/10.1080/00664670903278387

Andreasson, S. (2005). Orientalism and African Development Studies: The 'Reductive Repetition' Motif in Theories of African Underdevelopment. Third World Quarterly, 26(6), 971-986. Retrieved from https://doi.org/10.1080/01436590500089307

Ashcroft, B, G. Griffith \& H. Tiffin. (1995). (Eds.) The Post-colonial Studies Reader. London and New York: Routledge. . (1989). The Empire Writes Back. London: Routledge.

Astuti, S \& Taum, Y.Y. (September 2017). When the Earth Conquers the Heaven: A Study of Narratology on Kana Inai Abang Nguak in the Perspective of A. J. Greimas. International Journal of Humanity Studies, 1 (1), 1-16. Retrieved from https://doi.org/10.24071/ijhs.2017.010101

Bandel, K. (2013). Sastra Nasionalisme Pasca Kolonialitas. Yogyakarta: Pustaka Hariahara.

Beta, A. R. (2014). Hijabers: How Young Urban Muslim Women Redefine Themselves in Indonesia. International Communication Gazette, 76 (4-5) 377-389.

Bishop, R., Phillips, J., \& Yeo, W. W. (Eds.). (2013). Postcolonial Urbanism: Southeast Asian Cities and Global Processes. London: Routledge.

Bradnick, D. (2011). Postcolonial Theology. The Encyclopedia of Christian Civilization. Retrieved from https://onlinelibrary.wiley.com/doi/full/10.1002/9780470670606.wbecc109 5

Bräuchler, B. (2009). Cultural Solutions to Religious Conflicts? The Revival of Tradition in the Moluccas, Eastern Indonesia. Asian Journal of Social Science, $37(6), 872-891$.

Brett, M. G. (2008). Decolonizing God-the Bible in the Tides of Empire. Sheffield: Phoenix Press.

Brown, G. (2014). Does Framing Matter? Institutional Constraints on Framing in Two Cases of Intrastate Violence. Mobilization: An International Quarterly, 19(2), 143164. 
Buergin, R. (2004). Trapped in Environmental Discourses and Politics of Exclusion:

Karen in the Thung Yai Naresuan Wildlife Sanctuary in the Context of Forest and Hill Tribe Policies in Thailand. In Living at the Edge of Thai Society. London: Routledge, pp. 61-81.

Colm, S. (July-October 1997). Land Rights: the Challenge for Ratanakiri's Indigenous Communities. Watershed, 3 (1), 29-37.

Dewi, N. (2017). Under Children's Eyes: becoming pious in Tayeb Salih and Pramoedya Ananta Toer short stories. Al-Jami'ah: Journal of Islamic Studies, 55(1), 27-46. Retrieved from https://doi.org/10.14421/ajis.2017.551.27-46 . (2006). Membaca, menulis, dan membaca untuk menulis: diagnosis dini penulisan karya tulis di fakultas sastra. Susastra, 2 (3), 20-35. . (2006a). The death of Penan life: re-examination of "development" in Borneo. Arah Reformasi Indonesia, 30, 9-16.

During, S. (1995). Postmodernism or Postcolonialism. Landfall, 39 (3), 80-366. . (1987). Postmodernism or post-colonialism today. Textual Practice, 1(1),

32-47. Retrieved from https://doi.org/10.1080/09502368708582006

Ekpo, D. (2005). Chinua Achebe's early anti-imperialism in the court of postcolonial theory. Commonwealth: Essays and Studies, 27(2), 27. religion

Elegant, S. (2001). Without a trace. TIME Magazine, 3 September, 9-44.

Foucault, Michel. (1983). The subject and power. In Hubert Dreyfus and Paul Rabinow (eds.) Michel Foucault: beyond structuralism and hermeneutics, 2nd edn. Chicago: Chicago University Press.

Fox, J., Fujita, Y., Ngidang, D., Peluso, N., Potter, L., Sakuntaladewi, N., Sturgeon, J. and Thomas, D., 2009. Policies, political-economy, and swidden in Southeast Asia. Human Ecology, 37(3), 305-322.

Fukushima, M., Kanzaki, M., Hara, M., Ohkubo, T., Preechapanya, P., \& Choocharoen, C. (2008). Secondary forest succession after the cessation of swidden cultivation in the montane forest area in Northern Thailand. Forest Ecology and Management, 255(5-6), 1994-2006. Retrieved from https://doi.org/10.20495/tak.45.3_317

George, M. W. (2008). The elements of library research: what every student needs to know. Princeton: Princeton University Press.

Goh, B. L. (2005). Malay-Muslim spirits and Malaysian capitalist modernity: A study of keramat propitiation among property developers in Penang. Asia Pacific 
Viewpoint, 46(3), 307-321.

Hassim, N. (2014). A comparative analysis on hijab wearing in Malaysian Muslimah magazines. J. South East Asia Rese. Center Comm. and Humanities, 6, 79-96. Retrieved from http://search.taylors.edu.my/final_pdf/journals/Vol6_Issue1/Vol6_1_Mar14_7 _J5.pdf

Hassim, N., \& Khalid, N. L. (2015). Stailo \& sopan: modesty and Malay-Muslim women. In Int. Conference on Trends in Soc. Sci. Bus. and Humanities (TSSH-2015).

Haryatmoko. (2016). Membongkar rezim kepastian: pemikiran kritis post-strukturalis. Yogyakarta: Kanisius.

Hehanussa, J. M. (2009). Pela dan gandong: Sebuah model untuk kehidupan bersama dalam konteks pluralisme agama di Maluku. Gema Teologi, 33(1), 1-15. Retrieved from http://journaltheo.ukdw.ac.id/index.php/gema/article/view/40/35

Hirsch, P. (July-October 1997). Seeking culprits: ethnicity and resource conflict. Watershed, 3 (1), 25-28.

Johnson, D. (2010). Literary research and interdisciplinarity. In The handbook to literary research. Second edition. (Eds.) Correa, D.S. \& Owens, W. R. London: Routledge, 47-131.

Kampe, K. (1997). The Culture of development in developing indigenous peoples. In Development or domestication? Indigenous peoples of Southeast Asia. (Eds.) McCaskill \& Kampe. Chiang Mai: Silkworm, 6-26.

Keller, C. (Ed.). (2012). Postcolonial theologies: Divinity and empire. Saint Louis: Chalice Press.

King, R. (2009). Philosophy of religion as border control: globalization and the decolonization of the "love of wisdom" (philosophia). In Postcolonial philosophy of religion (pp. 35-53). Dordrecht: Springer.

Kwok, P. L. (2005). Postcolonial imagination and feminist theology. Louisville: Westminster John Knox Press.

Manser, B. (1996). Voices from the Rainforest: Testimonies of a Threatened People. Petaling Jaya: Bruno Manser Foundation and INSAN.

Mathiesen, T. (1997). The viewer society: Michel Foucault's 'panopticon' revisited. Theoretical Criminology, 1(2), 215-234. 
McCaskill, D. (1997). From tribal people to ethnic minorities: the transformation of indigenous peoples: a theoretical discussion. In Development or domestication? Indigenous peoples of Southeast Asia. (Eds.) McCaskill \& Kampe. Chiang Mai: Silkworm, pp. 26-60.

McCaskill, D \& Kampe, K. (1997). Eds. Development or domestication? Indigenous peoples of Southeast Asia. Chiang Mai: Silkworm, pp. 26-60.

Mignolo, Walter D. (2000). Local histories/global designs, coloniality, subaltern knowledges, and border thinking. Princeton, New Jersey: Princeton University Press.

Milallos, M. T. R. (2007). Muslim veil as politics: political autonomy, women and Syariah Islam in Aceh. Contemporary Islam, 1(3), 289-301.

Moore, S. D., \& Rivera, M. (Eds.). (2011). Planetary loves: Spivak, Postcoloniality, and Theology. New York: Fordham University Press.

Moore, S. D. (2008). The empire of God and the postcolonial era. Reflections: $A$ Magazine of Theological and Ethical Inquiry from Yale Divinity School. Retrieved from https://reflections.yale.edu/article/between-babel-andbeatitude/empire-god-and-postcolonial-era

Nwosu, M. (2007). The River, the Earth, and the Spirit World: Joseph Conrad, Chinua Achebe, Ben Okri, and the novel in Africa. Matatu, 35, 93.

Ouzgane, L., \& Okome, O. (2009). Encounters and Engagements with Things Fall Apart. Interventions, 11(2), 135-140.

Omiegbe, O. (2004). Chinua Achebe and Igbo (African) Traditional Religion. In Emerging perspectives on Chinua Achebe: Isinka, the Artistic Purpose: Chinua Achebe and the Theory of African Literature, 2, 187.

Purcell, W. F. (2013). Converting Culture: Reading Chinua Achebe's “Marriage is A Private affair" in light of Bernard Lonergan's theology of Conversion. Religion \& Literature, 81-101. Retrieved from http://www.jstor.org/stable/24397810

Pattiselano, J. T. F. (2014). Tradisi Uli, Pela dan Gandong pada masyarakat Seram, Ambon, dan Uliase. Antropologi Indonesia, 58, 58-70. Retrieved from https://doi/org/10.7454/ai.v0i58.3365

Peng, Li Hsun. (2016).Modern Hijab Style in Indonesia as an expression of Cultural Identity and Communication. Applied System Innovation (ICASI), 2016 International Conference on. IEEE. 
Restall, M. (2004). Seven Myths of the Spanish Conquest. Oxford: Oxford University Press.

Said, Edward W. (1991). Orientalism. London: Penguin Books.

Said, E. W. (1989). Representing the Colonized: Anthropology's Interlocutors. Critical Inquiry, $\quad$ 15(2), 205-225. $\quad$ Retrieved from http://www.jstor.org/stable/pdf/1343582.pdf?refreqid=excelsior\%3Ad8f4d3 cba75b0055614d0d6232467252

Santasombat, Y. (2004). Karen Cultural Capital and the political economy of Symbolic Power. Asian Ethnicity, 5(1), 105-120. Retrieved from https://doi.org/10.1080/1463136032000168925

Sloan, L. (2011). Women's Opression or Choice? One American's View on Wearing the Hijab. Affilia, 26(2), 218-221.

Soonsik Kim. (2004). Colonial and Postcolonial Discourse in the Novels of Yŏm SangSŏp, Chinua Achebe, and Salman Rushdie. New York: Peter Lang.

Sunardi, St. (November-Desember 2002). Ilmu Sosial berbasis sastra: catatan awal. Majalah Basis, 8-15.

Tiffin, H. (1988). 3. Post-colonialism, Post-modernism and the Rehabilitation of Postcolonial History. The Journal of Commonwealth Literature, 23(1), 169-181.

Trakarnsuphakorn, P. (1997). The Wisdom of the Karen in Natural Resource Conservation. In Development or Domestication? Indigenous Peoples of Southeast Asia. (Eds.) McCaskill \& Kampe. Chiang Mai: Silkworm, pp. 201-11.

Titaley, E. (2018). Pela dan Gandong Culture's Basic of a Network Formation for Poverty Alleviation in the Village. Advances in Social Sciences Research Journal, $5(3)$.

Wardaya, B.T. (2017). Beyond Borders: Notes on the Colonial and Post-Colonial Dynamics in the Americas, Europe and Indonesia. Yogyakarta: Sanata Dharma University Press.

Wood, D. M. (2007). Beyond the Panopticon? Foucault and Surveillance Studies. Space, Knowledge and Power: Foucault and Geography, 245-263.

Zitzer-Comfort, C. (2008). Teaching Native American Literature: Inviting Students to See the World through Indigenous Lenses. Pedagogy, 8(1), 160-170. 